\title{
PERAN BALAI PEMASYARAKATAN PADA SISTEM PERADILAN PIDANA ANAK DI TINJAU DALAM PERSPEKTIF HAK ASASI MANUSIA
}

\section{(The Role of Balai Pemasyarakatan on Juvenile Justice System Reviewed from Human Rights Perspective)}

\author{
Okky Chahyo Nugroho \\ Peneliti Pusat Penelitian dan Pengembangan Hak Asasi Manusia \\ Badan Penelitian dan Pengembangan Hukum dan HAM \\ Kementerian Hukum dan HAM RI \\ JI. HR. Rasuna Said Kav 4-5 Jakarta Selatan \\ email: okies_ham@yahoo.com
}

Tulisan Diterima: 03-11-2017; Direvisi: 20-11-2017; Disetujui Diterbitkan: 24-11-2017

\begin{abstract}
Children involved in the criminal justice system for law violation should be of special concern by law enforcers. The Penal Institution (Balai Pemasyarakatan) must, of course, play major role in providing recommendations to the police, prosecutors and courts to protect the children's rights. The children in the national and international human rights instruments pose a position as a vulnerable group that deserve special treatments, and the state is responsible to ensure the fulfilment of such privileges. Consequently, it is necessary to review the Human Rights aspects in the counselling and advocating system applied by the Penal Institution (Balai Pemasyarakatan) to the children in conflict with the law. The goal is to identify the protection of the rights of the children in conflict with the law during the counselling and advocating process by the Penal Institution (Balai Pemasyarakatan). The method used in this paper is descriptive qualitative analysis of the data collected from primary legal materials, secondary legal materials, and documents of study materials or literature. According to the discussion in this paper, it is evident that the protection of the children rights in the counselling and advocating system by the Penal Institution (Balai Pemasyarakatan) has not been optimum as one may find delayed public research and advocation by the Penal Institution (Balai Pemasyarakatan) so that it is necessary to strengthen of institutional capacity, as the Penal Institution (Balai Pemasyarakatan) plays significant roles in the protection of children rights, as may be provided for in the Law of Juvenile Criminal Justice System.
\end{abstract}

Keywords: Children Rights, Balai Pemasyarakatan, Juvenille Justice System.

\begin{abstract}
ABSTRAK
Anak masuk dalam sistem peradilan pidana karena melakukan pelanggaran hukum harus menjadi perhatian khusus oleh para penegak hukum, tentunya Balai Pemasyarakatan mempunyai peran besar dalam memberikan rekomendasi kepada pihak kepolisian, kejaksaan, pengadilan dalam rangka perlindungan hak anak. Posisi anak-anak dalam instrumen HAM nasional dan internasional ditempatkan sebagai kelompok rentan yang harus diberlakukan istimewa, dan negara mempunyai tanggung jawab untuk menjamin pemenuhan hak-hak istimewa tersebut. Oleh sebab itu, hal yang perlu di kaji adalah mengenai aspek hak asasi manusia dalam sistem pembimbingan dan pendampingan yang dilakukan oleh Balai Pemasyarakatan terhadap anak yang berkonflik dengan hukum. Tujuannya adalah untuk mengindentifikasi perlindungan hak anak yang berkonflik dengan hukum dalam pembimbingan dan pendampingan yang dilakukan Balai Pemasyarakatan. Metode yang digunakan dalam tulisan ini adalah analisis kualitatif deskriptif melalui data yang dikumpulkan bahan hukum primer, bahan hukum sekunder, dan bahan-bahan studi dokumen atau kepustakaan. Berdasarkan pembahasan dalam tulisan ini dapat dikemukakan belum maksimalnya perlindungan hak anak dalam sistem pembimbingan dan pendampingan oleh BAPAS, yaitu: masih ditemukan keterlambatan pembuatan litmas dan pendampingan oleh BAPAS, sehingga diperlukan penguatan kapasitas lembaga, karena peran BAPAS menjadi sangat penting di dalam perlindungan anak, sebagaimana yang telah diatur dalam Undang-Undang Sistem Peradilan Pidana Anak.
\end{abstract}

Kata Kunci: Hak Anak, Balai Pemasyarakatan, Sistem Peradilan Pidana Anak. 


\section{PENDAHULUAN}

Anak adalah bagian yang tidak terpisahkan dari keberlangsungan hidup manusia dan keberlangsungan sebuah bangsa dan negara. Dalam Konstitusi Indonesia, anak memiliki peran strategis yang secara tegas dinyatakan bahwa negara menjamin hak setiap anak atas kelangsungan hidup, tumbuh, dan berkembang serta atas perlindungan dari kekerasan dan diskriminasi. ${ }^{1}$ Anak bukanlah miniatur orang dewasa, maka dengan ciri dan sifat anak yang khas tersebut perlu ditentukan pembedaan perlakuan. ${ }^{2}$ Hal tersebut dimaksud untuk lebih melindungi dan mengayomi anak agar dapat menyongsong masa depannya. ${ }^{3}$ Dengan segala potensi yang dimiliki, tidak mustahil anak-anak pada masa sekarang akan berperan dalam meningkatkan laju pembangunan bangsa di masa yang akan datang. ${ }^{4}$ Untuk kelangsungan pertumbuhan anak baik mental maupun fisik serta interaksi dalam pergaulan bermasyarakat, maka anak harus benarbenar mendapat perhatian khusus. Selain itu juga perlakuan terhadap anak harus benar-benar diperhatikan dan diperlakukan secara hati-hati dan konseptual sehingga potensi yang melekat dalam diri anak dapat tumbuh dan berkembang dengan baik dan seimbang. ${ }^{5}$

Anak adalah subjek yang mempunyai perasaan, pikiran, keinginan dan harga diri. Mereka harus diberi peluang untuk didengar dan dihargai pendapatnya dalam hal-hal menyangkut kepentingan mereka. ${ }^{6}$ Perkembangan dunia yang begitu cepat tidak lain merupakan hasil dari perkembangan pemikiran manusia, baik yang memberikan dampak positif maupun dampak negatif. ${ }^{7}$ Mental anak yang masih dalam tahap pencarian jati diri, kadang mudah terpengaruh dengan situasi dan kondisi lingkungan di sekitarnya. ${ }^{8}$ Sehingga apabila lingkungan tempat anak berada tersebut buruk, dapat terpengaruh pada tindakan yang dapat melanggar hukum. Hal itu tentu saja dapat merugikan dirinya sendiri dan masyarakat. Tidak sedikit tindakan tersebut akhirnya menyeret mereka berurusan dengan aparat penegak hukum. ${ }^{9}$

Di Indonesia, masalah anak yang berkonflik dengan hukum mempunyai kecenderungan semakin meningkat. Catatan kriminalitas terkait anak di Indonesia seperti yang diungkapkan oleh Direktur Bimbingan Kemasyarakatan dan Pengentasan Anak Ditjen Pemasyarakatan menunjukkan data bahwa anak yang berada di lingkungan rutan dan lapas berjumlah 3.812 orang. Anak yang diversi sebanyak 5.229 orang, dan total sekitar 10 ribu anak termasuk mereka yang sedang menjalani asimilasi, pembebasan bersyarat dan cuti jelang bebas. ${ }^{10}$ Data tersebut menunjukkan jumlah anak yang berkonflik di Indonesia cukup banyak.

Maraknya kasus hukum yang menimpa anakanak di Indonesia, bukan berarti mereka sama seperti orang dewasa yang sudah mempunyai akal dan pengalaman. Perilaku ironi anak-anak lebih banyak disebabkan lingkungan sosial, keluarga dan gagalnya tanggung jawab negara untuk memenuhi hak-hak mereka. Posisi anak-anak dalam instrumen HAM nasional dan internasional ditempatkan sebagai kelompok rentan yang harus diberlakukan istimewa, dan negara mempunyai tanggung jawab untuk menjamin pemenuhan hakhak istimewa tersebut. ${ }^{11}$

Pasal 40 Konvensi Hak Anak sebagaimana telah diratifikasi oleh Pemerintah Indonesia melalui Keputusan Presiden Nomor 36 Tahun 1990 tentang Pengesahan Convention on the Rights of the Child (Konvensi Hak-hak Anak) memberikan definisi

\footnotetext{
Penjelasan Undang-Undang Nomor 11 Tahun Tahun 2012 Tentang Sistem Peradilan Pidana Anak

Susilowati, Upaya Meminimalisasi Penggunaan Pidana Penjara Bagi Anak, (Semarang, Universitas Diponogoro, 2008$).$ Hlm 9. Ibid

Ibid

Ibid

Ibid

Ibid

8. Novie Amalia Nuraheni, Sistem Pembinaan Edukatif Terhadap Anak Sebagai Pelaku Tindak Pidana (Semarang : Universitas Diponogoro, 2009), hlm 1

10. http://www.pikiran-rakyat.com/bandungraya/2015/o8/o4/337054/sepuluh-ribu-anak-kiniberhadapan-dengan-hukum, diakses tanggal 26 Oktober 2017.

11. Dalam instrumen internasional kelompok rentan itu meliputi, refugees, internally displaced persons (IDPS), national minorities, migrant workers, indigenous peoples, children; dan women. Sedangkan dalam UU No. 39 tahun 1999 tentang HAM Indonesia dalam penjelasannya disebutkan bahwa kelompok rentan itu meliputi orang lanjut usia, anakanak, fakir miskin, wanita hamil dan penyandang cacat.
}

9. $\quad$ Ibid 
yang dimaksud dengan "Anak yang berkonflik dengan hukum adalah anak yang disangka, dituduh atau diakui sebagai telah melanggar undang-undang hukum pidana". ${ }^{2}$ Majelis Umum PBB dalam Standard Minimum Rules for the Administration of Juvenile Justice ${ }^{13}$ atau yang dikenal dengan Beijing Rules mendefinisikan anak yang berkonflik dengan hukum " $a$ child or young person who is alleged to have committed or who has been found to have committed an offence.

Salah satu hak istimewa anak ketika berhadapan dengan hukum adalah dalam penanganan kasus hukumnya harus diberlakukan berbeda dengan orang-orang dewasa. ${ }^{14}$ Pada Pasal 27 Ayat (1) Undang-Undang Nomor 11 Tahun 2012 tentang Sistem Peradilan Pidana Anak menyatakan "Dalam melakukan penyidikan terhadap perkara anak, Penyidik wajib meminta pertimbangan atau saran dari Pembimbing Kemasyarakatan setelah tindak pidana dilaporkan atau diadukan". Ayat (2) menyatakan "Dalam hal dianggap perlu, Penyidik dapat meminta pertimbangan atau saran dari ahli pendidikan, psikolog, psikiater, tokoh agama, pekerja sosial profesional atau tenaga kesejahteraan sosial, dan tenaga ahli lainnya".

Perlakuan istimewa terhadap anak yang berkonflik dengan hukum telah dijamin dalam instrumen-instrumen hukum HAM nasional dan internasional, baik Undang-Undang Nomor 11 Tahun 2012 tentang Sistem Peradilan Pidana Anak, Undang-Undang Nomor 35 Tahun 2016 tentang Perlindungan Anak, dan atau instrumen hukum HAM internasional seperti Konvensi tentang Hak-Hak Anak, Peraturan-peraturan Minimum Standar PBB Mengenai Administrasi Peradilan bagi Anak (Beijing Rules) dan Pedoman PBB dalam Rangka Pencegahan Tindak Pidana Anak (The Riyadh Guidelines). Namun, sampai saat ini, pelanggaran hak anak yang bermasalah dengan hukum masih berlangsung. Penanganan terhadap anak bermasalah dengan hukum tidak jauh berbeda dengan penanganan kasus yang dihadapi orang dewasa. ${ }^{15}$

Perlakuan istimewa dituangkan dalam Prinsip Juvenile Court di Amerika Serikat. Sebagaimana dicatat oleh Green Wood, antara lain:
Pertama, menjunjung asas praduga tidak bersalah, dengan menyatakan bahwa pelanggaran hukum yang dilakukan seorang anak bukan sebagai kejahatan melainkan sebagai perilaku delinkuensi yang merupakan perwujudan dari belum mampunya seorang anak untuk bertanggung jawab.

Kedua, penempatan anak dalam lembaga bukan sebagai penghukuman melainkan untuk mendapat pembinaan dan resosialisasi sementara pada orang dewasa vonis.

Ketiga, dalam proses persidangan anak bersifat tertutup, artinya hanya diketahui oleh keluarga dan pihak-pihak yang terlibat dalam peradilan, sementara pada orang dewasa persidangan bersifat terbuka untuk umum.

Keempat, pada peradilan anak hadir seorang pekerja sosial yang memberikan social report guna memberikan rekomendasi bagi hakim mengenai penempatan.

Kelima. Masa pembinaan anak dalam lembaga lebih singkat daripada orang dewasa.

Keenam, dituntut adanya pemisahan antara pelaku delinkuensi dan pelanggaran dewasa baik selama dalam proses peradilan hingga menjalani hukuman.

Ketujuh, dalam menangani kasus delinkuensi harus diputuskan lebih cepat dari kasus orang dewasa dan disposisi atau penempatan hakim harus bervaria.

Oleh karenanya pelaksanaan Sistem Pemasyarakatan mempunyai tujuan akhir yaitu terciptanya kemandirian warga binaan Pemasyarakatan atau membangun manusia mandiri. ${ }^{16}$ Sistem Peradilan pidana dalam kerangka merupakan rangkaian kegiatan yang dilakukan dalam rangka menegakkan hukum pidana dan menjaga ketertiban sosial, dilaksanakan mulai kerja polisi dalam melakukan penyidikan peristiwa pidana, penuntutan oleh Jaksa Penuntut Umum, pemeriksaan perkara di pengadilan dan pelaksanaan hukuman di Lapas, Rutan dan Cabang Rutan. Seluruh rangkaian kegiatan tersebut harus saling mendukung secara sinergis sehingga tujuan

12. Lihat Pasal 40 ayat (1) KHA

13. General Assembly resolution 40/33 of 29 November 1985

14. M. Syafii, Loc.Cit

15. Ibid

16. Gunarto, Peranan Bapas Dalam Perkara Anak, diunduh dari http://bangopick.wordpress.com/20o8/o2/o9/peranan-bapas-dalamperkara-anak/ diakses tanggal 26 Oktober 2017 
dari Sistem Peradilan Pidana tersebut dapat tercapai. ${ }^{17}$

Salah satu kegiatan dalam rangkaian kegiatan sistem peradilan pidana tersebut dilaksanakan oleh Balai Pemasyarakatan (BAPAS) yang merupakan bagian dari kegiatan sub sistem pemasyarakatan narapidana atau sub-sub sistem peradilan pidana. ${ }^{18}$ Kedudukan hukum dalam peraturan perundangan Indonesia dapat ditemukan dalam Undang-Undang Nomor 12 Tahun 1995 Tentang Pemasyarakatan. Dalam Pasal 1 angka 4 di rumuskan bahwa Balai Pemasyarakatan yang selanjutnya disebut BAPAS adalah pranata untuk melaksanakan bimbingan Klien Pemasyarakatan. Adapun Klien Pemasyarakatan dirumuskan sebagai seseorang yang berada dalam bimbingan BAPAS (Pasal 1 Angka 9). Peran BAPAS tersebut dapat dilihat pada Peraturan Pemerintah Nomor 1 Tahun 1999 Tentang Pembinaan dan Pembimbingan Warga Binaan Pemasyarakatan. Menurut Pasal 1 Angka 6, Petugas Pemasyarakatan yang melaksanakan tugas pembimbingan klien pemasyarakatan disebut sebagai pembimbing Kemasyarakatan. Dengan demikian dalam tugasnya melakukan pembimbingan terhadap klien pemasyarakatan.

Berdasarkan uraian di atas, maka hal yang perlu dikaji adalah mengenai aspek hak asasi manusia dalam peran BAPAS terhadap anak yang berkonflik dengan hukum dalam rangka kepentingan terbaik bagi anak melalui penguatan kelembangan. Tujuannya adalah untuk mengindentifikasi perlindungan hak anak yang berkonflik dengan hukum dalam tugas dan fungsi yang dilakukan BAPAS.

\section{METODE PENELITIAN}

Metode kualitatif dikembangkan untuk mengkaji kehidupan manusia dalam kasus-kasus terbatas, sifatnya kasuistik namun mendalam (in depth) dan bersifat total atau menyeluruh (holistic), dalam arti tidak mengenal pemilahan-pemilahan gejala secara konseptual ke dalam aspek-aspeknya yang eksklusif. ${ }^{19}$

Teknik pengumpulan data bersumber pada data sekunder. Data sekunder diperoleh dari bahan hukum primer mengenai ketentuan yang mengatur Peradilan Anak, tugas dan fungsi Bapas serta bahan-bahan studi dokumen atau kepustakaan seperti buku, majalah, makalah, jurnal, hasil penelitian dan situs internet yang berkaitan dengan objek yang ditulis.

Analisis data dilakukan dengan metode analisis kualitatif dengan penguraian secara deskriptif(pemaparan).Analisiskualitatifdeskriptif yang digunakan dalam tulisan ini memberikan pertimbangan bahwa tidak hanya dimaksudkan untuk mengungkapkan atau menggambarkan data yang dikumpulkan sebagaimana adanya, namun bahan hukum primer, bahan hukum sekunder, dan bahan-bahan studi dokumen atau kepustakaan yang ada akan di check and re-check (triangulasi) untuk ditemukan titik tengah dan akurasi pendapat dari berbagai pandangan sehingga menghasilkan suatu kesimpulan.

\section{PEMBAHASAN}

\section{A. Paradigma Penanganan Anak yang Berkonflik dengan Hukum}

Sistem Peradilan Anak dijadikan pedoman bagi penegak hukum untuk mengambil suatu keputusan yang bijak dalam hal apakah penjatuhan sanksi pidana terhadap anak merupakan keputusan yang tepat untuk kepentingan terbaik bagi anak ataukah sebaliknya. Sudarto dalam bukunya Sambas menjelaskan bahwa pidana adalah penderitaan yang sengaja dibebankan kepada orang yang melakukann perbuatan yang memenuhi syarat-syarat tertentu. ${ }^{20}$

Sedangkan pemidanaan merupakanakibat dari pelanggaran hukum berupa pidana. ${ }^{21}$ Pemidanaan anak pada umumnya berbeda dengan pemidanaan orang dewasa. Pemidanaan terhadap anak lebih mengutamakan kepentingan terbaik bagi anak. Ancaman pidana terhadap anak adalah 1/2 (satu per dua) dari ancaman pidana orang dewasa kecuali tindak pidana yang diancam dengan pidana mati atau pidana penjara seumur hidup, maka pidana yang dijatuhkan adalah pidana penjara paling lama 10 (sepuluh) tahun. Hal tersebut merupakan salah

19. Sutandyo Wignjosoebroto, “Hukum Konsep dan Metode”, (Malang: Setara Press, 2013), hlm. 130.

20. Nandang Sambas, Pembaruan Sistem Pemidanaan Anak di Indonesia, Bandung: Refika Aditama, 2010. Hlm 12.

21. Prasetyo dan Halim. Politik Hukum Pidana. Yogyakarta: Pustaka Pelajar 2005.Hlm 73.
} 
satu contoh perbedaan perlakuan anak dengan orang dewasa pada umumnya. Berdasarkan Instrumen Internasional yang mengatur masalah perilaku delinkuensi anak dapat diklasifikasikan ke dalam criminal offence (perilaku delinkuensi anak yang merupakan tindak pidana apabila dilakukan oleh orang dewasa) dan status offence (perilaku delikuensi anak yang erat kaitanya dengan statusnya sebagai anak). ${ }^{22}$ Hal tersebut, tidaklah tepat apabila tujuan pemidanaan anak disejajarkan dengan pemidanaan orang dewasa. Pemidanaan anak telah diatur dalam Undang-Undang No 11 tahun 2012 tentang Sistem Peradilan Pidana Anak. Dalam mengutamakan pendekatan keadilan restoratif baik dari tingkat penyidikan, penuntutan, maupun dalam persidangan.

Terdapat 3 (tiga) paradigma peradilan anak yang terkenal, yaitu: paradigma pembinaan individual (individual treatment paradigm) yang menekankan pada permasalahan yang dihadapi pelaku bukan pada perbuatan/kerugian yang diakibatkan; paradigma retributif (retributive paradigm) dimana penjatuhan sanksi dalam paradigma retributif ditentukan pada saat pelaku menjalani pidana; paradigma restoratif (restorative paradigm), bahwa di dalam mencapai tujuan penjatuhan sanksi, maka diikutsertakan korban untuk berhak aktif terlibat dalam proses peradilan, indikator pencapaian tujuan penjatuhan sanksi tercapai dengan dilihat apakah korban telah direstorasi, kepuasan korban dan lain sebagainya. ${ }^{23}$

Di Indonesia sistem peradilan pidana anak menggunakan paradigma restoratif yaitu mengutamakan keadilan restoratif. Kewajiban mengutamakan keadilan restoratif tercantum dalam Pasal 5 Undang-Undang No. 11 tahun 2012. Salah satu upaya untuk mencapai keadilan restoratif adalah melalui upaya diversi yang merupakan pengalihan penyelesaian perkara anak dari proses peradilan pidana ke proses di luar peradilan pidana. Upaya diversi diwajibkan mulai tingakat penyidikan, penuntutan, dan pemeriksaan perkara anak di pengadilan negeri.

Apabila kewajiban pengupayaan diversi sengaja tidak dilaksanakan baik oleh penyidik, penuntut umum, ataupun hakim maka sanksi pidana akan dijatuhkan kepadanya. Akan tetapi penjatuhan sanksi pidana tersebut dinyatakan tidak mempunyai kekuatan hukum mengikat oleh Mahkamah Konstitusi dalam Putusan Mahakamah Konstitusi Nomor 110/PUU-X/2012. Penanganan serta perlakuan yang baik dan tepat terhadap anak yang melakukan tindak pidana sangatlah berpengaruh terhadap psikologi anak. Maka dari itu dibutuhkan peran suatu lembaga khusus serta aparat khusus untuk menangani anak yang berhadapan dengan hukum baik di tingkat kepolisian, kejaksaan, dan pengadilan. Selain itu perlu diingat bahwa tindak pidana yang dilakukan oleh anak tidak hanya merugikan anak itu sendiri melainkan juga merugikan masyarakat.

Di pengadilan nasib anak digantungkan kepada hakim. Hakim anak sebagai pemutus perkara anak, mempunyai peran penting dalam menentukan nasib anak ke depan. Sebagaimana ditegaskan oleh Purniati dan kawan-kawan dalam bukunya Sri Sutatiek bahwa "dalam sistem peradilan di Indonesia menempatkan hakim sebagai institusi yang paling menentukan atas nasib anak". ${ }^{24}$ Hakim anak dalam memutus perkara anak harus mendahulukan kepentingan serta kesejahteraan anak itu sendiri. Keutamaan mendahulukan kepentingan serta kesejahteraan anak melebihi dari kepentingan masyarakat. Hal tersebut sebagaimana disampaikan oleh almarhum Prof Sudarto dalam buku bunga rampai hukum pidana bahwa "Walaupun di dalam RUU disebutkan pengadilan anak mengutamakan kesejahteraan anak di samping kepentingan masyarakat, tetapi beliau tetap berpendapat, bahwa kepentingan anak tidak boleh dikorbankan demi kepentingan masyarakat". ${ }^{25}$

Mendahulukan kesejahteraan serta kepentingan anak juga tercantum dalam Standard Minimum Rules for the Administration of Juvenile Justice (SMR-JJ) atau yang dikenal dengan istilah Beijing Rules. Dalam Rule 5.1 Aims of Juvenile Justice ditegaskan bahwa The juvenile justice system shall emphasize the well being of

22. Opcit, Sambas, 2010. Hlm 24

23. Wahyudi, S..Implementasi Diversi dalam Pembaharuan Sistem Peadilan Pidana Anak di Indonesia.Purwokerto;Genta Publishing, 2011. Hlm 38,39

24. Sutatiek. Rekonstruksi Sistem Sanksi dalam Hukum Pidana Anak di Indonesia, Urgensi Penerbitan Panduan Pemidanaan (The Sentencing Guidlines) untuk Hakim Anak. Yogyakarta: Aswaja Presindo, 2013. Hlm 29.

25. Muladi dan Barda Nawawi, A. Bunga Rampai Hukum Pidana. Bandung: PT. Alumni, 2010. Hlm 120 
the juvenile and shall ensure that any reaction to juvenile offenders shall always be in proportion to the circumstances of both the offender and the offence. Dalam Commentary Rule 5.1 tersebut di atas terdapat dua tujuan penting terkait dengan kejahatan anak, yaitu memajukan kesejahteraan anak yang berarti menghindarkan sanksi yang bersifat menghukum dan prinsip proposionalitas yaitu prinsip yang merupakanalat untuk mengekang penggunaan sanksi yang bersifat menghukum dalam arti semata-mata untuk pembalasan. ${ }^{26}$

Berdasarkan penjelasan tersebut di atas, dapat diperoleh pemahaman bahwa dalam menyelesaikan perkara anak yang berkonflik dengan hukum harus mengedepankan kebaikan dan kepentingan anak itu sendiri guna mensejahterakan dan melindungi anak dari stigma negatif akibat dari proses hukum yang dijalani. Hakim anak yang merupakan pejabat peradilan yang diberi wewenang oleh undang-undang untuk mengadili sekaligus sebagai penentu nasib anak harus mengedepankan prinsip kepentingan terbaik bagi anak agar kesuksesan peradilan anak dapat di-capai dengan baik.

\section{B. Peran Balai Pemasyarakatan dalam Penanganan Anak yang Berkonflik dengan Hukum}

Undang-Undang Nomor 11 Tahun 2012 tentang Sistem Peradilan Pidana Anak membuat pembimbing dan pendampingan kemasyarakatan mempunyai dasar hukum yang kuat dalam tugasnya membuat litmas, hadir dalam sidang sebagai anggota sidang anak dan membimbing klien (anak yang berkonflik dengan hukum). Selain itu BAPAS mempunyai peran dan fungsi dalam melaksanakan penelitian kemasyarakatan yang digunakan sebagai bahan pertimbangan oleh Penyidik dalam proses diversi di tingkat kepolisian, maupun ketika proses diversi di tingkat pengadilan.

Selain itu laporan penelitian kemasyarakatan digunakan pula sebagai salah satu bahan pertimbangan hakim dalam memutus perkara anak yang berkonflik dengan hukum, sebagaimana tercantum dalam Pasal 60 Ayat (3) Undang-Undang Nomor 11 Tahun 2012 Tentang Sistem Peradilan
Pidana Anak. Apabila kewajiban tersebut tidak dilaksanakan oleh hakim, maka terdapat implikasi yuridis berupa putusan batal demi hukum (Pasal 60 Ayat (4) Undang-Undang Nomor 11 Tahun 2012 Tentang Sistem Peradilan Pidana Anak). Seperti yang dijelaskan juga oleh Sambas bahwa Anak berkonflik dengan hukum yang melewati tahapantahapan pengadilan tanpa kehadiran pendamping atau salah satunya BAPAS cenderung untuk terjerumus kembali kedalam pelanggarannya baik itu dengan kasus yang sama ataupun dengan kasus yang berbeda. ${ }^{27}$

BAPAS adalah salah satu pihak yang terlibat selama proses peradilan Anak yang berkonflik dengan hukum dari awal anak ditangkap hingga anak menyelesaikan masa hukumannya. Hal ini membuat BAPAS memiliki peran yang penting dalam proses peradilan Anak yang berkonflik dengan hukum. Secara umum peran BAPAS dalam proses peradilan Anak yang berkonflik dengan hukum terbagi menjadi 3 tahap, yaitu tahap sebelum sidang pengadilan (pra adjudikasi) yakni penyidikan, tahap saat sidang pengadilan (adjudikasi) yakni pendampingan di persidangan dan tahap setelah pengadilan (post adjudikasi) yakni pengawasan dan pembimbingan bagi Anak yang berkonflik dengan hukum. ${ }^{28}$

Berdasarkan penjelasan tersebut di atas, maka dapat dikemukakan bahwa peran dan fungsi BAPAS dalam menangani perkara anak yang berkonflik dengan hukum sangat penting demi tercapainya tujuan dari sistem peradilan pidana anak.

Karena dengan adanya laporan penelitian kemasyarakatan, diharapkan keputusan yang diambil oleh hakim tidak melukai rasa keadilan dan dapat terwujud sistem peradilan pidana yang menjamin perlindungan kepentingan terbaik bagi anak, sehingga stigma negatif terhadap anak yang berkonflik dengan hukum dapat dihindarkan. Dalam penjelasan umum UndangUndang Sistem Peradilan Pidana dijelaskan bahwa tujuan dari sistem peradilan pidana anak adalah untuk mewujudkan peradilan yang benar-benar menjamin perlindungan kepentingan terbaik bagi anak yang berhadapan dengan hukum sebagai penerus bangsa.

26. Ibid. Hlm 121

27. Nandang Sambas, Peradilan Pidana Anak di Indonesia dan Instrumen Internasional PerlindunganAnak serta Penerapannya, Yogyakarta: Graha Ilmu, 2013. Hlm 35.

28. Nashriana. Perlindungan Hukum Pidana Bagi Anak di Indonesia. Depok: Raja Grafindo Persada, 2012. Hlm 110-116. 


\section{Konsep Balai Pemasyarakatan dalam Pembimbingan dan Pendampingan terhadap Anak yang Berkonfilk dengan Hukum}

Sistem Peradilan Pidana Anak, Hakim Anak dalam mengambil serta membuat keputusan tentu dipengaruhi oleh beberapa hal diantaranya adalah Laporan Penelitian Kemasyarakatan dari BAPAS yang sangat membantu hakim dalam memutus suatu perkara anak dengan melihat latar belakang anak dan motif anak melakukan kejahatan. Membuat laporan kemasyarakatan merupakan suatu kewajiban yang harus dilaksanakan oleh Pembimbing Kemasyarakatan. Hal tersebut tercantum dalam Pasal 13 huruf (b) Keputusan Bersama Ketua Mahkamah Agung, Jaksa Agung, Kepala Kepolisian, Menteri Hukum dan HAM, Menteri Sosial, dan Menteri Pemberdayaan Perempuan dan Perlindungan Anak bahwa BAPAS wajib membuat laporan penelitian pemasyarakatan $^{29} \quad$ Sedangkan Pembimbing Kemasyarakatan adalah BAPAS yang berdasarkan Pasal 64 ayat (1) Undang-Undang No 11 Tahun 2012 mempunyai tugas melakukan penelitian kemasyarakatan, pendampingan, pembimbingan, dan pengawasan terhadap anak serta membuat Laporan penelitian kemasyarakatan digunakan untuk kepentingan penyidikan, penuntutan, dan persidangan.

Hal senada dikatakan oleh Gultom bahwa hakim dalam mengambil keputusan terkait perkara anak, terdapat beberapa faktor yang mempengaruhi hakim salah satunya adalah laporan hasil Penelitian Kemasyarakatan dari BAPAS yang dalam laporan tersebut dijelaskan mengenai latar belakang dan keadaan anak. Selain itu pertimbangan terkait dengan psikologi anak tetap harus diperhatikan oleh hakim dalam mengambil keputusan. Hal tersebut semata-mata untuk kebaikan anak itu sendiri. Penanganan yang salah dalam proses pengadilan anak, dapat menimbulkan pertumbuhan mentalitas atau kejiwaan anak negatif dan berbahaya bagi penciptaan generasi muda untuk masa mendatang. ${ }^{30}$
Laporan Pembimbing Kemasyarakatan untuk kepentingan persidangan mencakup hal-hal sebagai berikut :

1. Data pribadi anak, keluarga, pendidikan, dan kehidupan sosial;

2. Latar belakang dilakukanya tindak pidana;

3. Keadaan korban dalam hal ada korban dalam tindak pidana terhadap tubuh atau nyawa;

4. Hal lain yang dianggap perlu;

5. Berita acara diversi; dan

6. Kesimpulan dan rekomendasi dari pembimbing kemasyarakatan. ${ }^{31}$

Pasal 60 Ayat (3) Undang-Undang No.11 tahun 2012 tentang Sistem Peradilan Pidana Anak bahwa Hakim wajib mempertimbangkan laporan penelitian kemasyarakatan dari Pembimbing Kemasyarakatan sebelum menjatuhkan putusan perkara. Apabila hakim tidak mempertimbangkan laporan penelitian kemasyarakatan dalam putusanya, maka putusan hakim tersebut batal demi hukum. Selain itu Laporan penelitian kemasyarakatan oleh Pembimbing Kemasyarakatan sangat berpengaruh terhadap sukses atau tidaknya peradilan anak.

Hal tersebut sebagaimana dijelaskan oleh Hawnah Scaft yang dikutip dalam penelitian Anggraeni, ${ }^{32}$ menyatakan bahwa:

Suksesnya peradilan anak jauh lebih banyak tergantung pada kualitas dari probation officer (petugas BAPAS) daripada hakimnya. Peradilan anak yang tidak memiliki korps pengawasan percobaan yang membimbing dengan bijaksana dan kasih sayang ke dalam lingkungan kehidupan anak dan memberikan petunjuk bagi standar pemikiran yang murni bagi anak mengenai hidup yang benar, hanyalah mengakibatkan fungsi peradilan anak menjadi kabur kalau tidak ingin menjadi sia-sia.

Berdasarkan penjelasan tersebut di atas, dapat diperoleh pemahaman bahwa kesuksesan suatu peradilan anak tergantung pada seberapa besar kualitas dari probation officer (petugas BAPAS) yang dimaksud dalam hal ini adalah Pembimbing Kemasyarakatan dalam melakukan penelitian

\footnotetext{
29. Margaretha, dkk. Buku Panduan Penanganan Anak Berhadapan dengan Hukum.Jakarta:P2TP2A (Pusat pelayanan terpadu pemberdayaan perempuan dan anak), 2012. Hlm 74.

30. Maidin Gultom. Perlindungan Hukum terhadap Anak.Bandung: PT. Refika Aditama, 2013. Hlm 125.

31. Op.Cit, Hlm 32-34.

32. Anggraeni U.R.Jurnal Supermasi Hukum: Peranan Pembimbing Kemasyarakatan di dalam Sistem Peradilan Pidana Anak di Kota Bengkulu. Bengkulu: Universitas Bengkulu.Volume 22 No.1. Januari 2013. Hlm 116.
} 
dan membuat laporan penelitian kemasyarakatan. Kualitas laporan penelitian kemasyarakatan yang digunakan hakim sebagai dasar pertimbangan sangat mempengaruhi terhadap nasib anak.

Berdasarkan penjelasan tersebut di atas, dapat ditegaskan bahwa laporan penelitian kemasyarakatan berpengaruh terhadap hakim sebelum menjatuhkan putusan perkara. Akan tetapi dalam implementasinya terkadang hakim seakanakan tidak mengindahkan laporan penelitian kemasyarakatan. Misalnya dalam kasus pencurian tiga (3) ekor bebek di Purbalingga dijatuhi hukuman pidana. Seperti yang dilangsir oleh media Suara Merdeka.com diterangkan bahwa dalam kasus pencurian tiga (3) ekor bebek di Purbalingga, hakim Pengadilan Negeri Purbalingga dalam memutus perkara tidak mengindahkan saran BAPAS untuk melakukan tindakan dikembalikan ke orang tua. Akan tetapi hakim memilih menjatuhkan vonis hukuman 2 (dua) bulan 15 (lima belas hari) hari (Suara Merdeka.com). Dalam kasus pencurian bebek di Purbalingga sebagaimana dijelaskan di atas, dapat diperoleh pemahaman bahwa hakim dalam memutus perkara anak tersebut tidak mengindahkan laporan penelitian serta saran dari BAPAS, padahal sudah ditentukan dengan jelas dalam ketentuan perundang-undangan bahwa hakim wajib mempertimbankan laporan Penelitian Kemasyarakatan.

\section{Upaya Balai Pemasyarakatan dalam Melindungi Hak Anak yang Berkonflik Hukum}

Perlindungan hak anak yang berhadapan dengan hukum dalam konteks HAM Internasional merupakan salah satu bagian dari serangkaian kewajiban yang harus dipenuhi oleh negara yaitu untuk: menghormati (to respect), melindungi (to protect), dan memenuhi (to fulfill). Secara normatif, berlandaskan pada standar Hak Asasi Manusia Internasional maupun Konstitusi (termasuk ketentuan HAM secara nasional) dan secara operasional ditujukan untuk memajukan pelaksanaan HAM.

Menghormati (obligation to respect): merupakan kewajiban aparat penegak hukum khususnya Bapas untuk tidak turut campur untuk mengatur warga negaranya ketika melaksanakan haknya. Dalam hal ini memiliki kewajiban untuk tidak melakukan tindakan-tindakan yang akan menghambat pemenuhan dari seluruh hak asasi anak. ${ }^{33}$

Melindungi (obligation to protect): merupakan kewajiban aparat penegak hukum khususnya Bapas agar bertindak aktif untuk memberi jaminan perlindungan terhadap hak asasi anak. Dalam hal ini berkewajiban untuk mengambil tindakan-tindakan untuk mencegah pelanggaran semua hak asasi anak oleh oknum penegak hukum. ${ }^{34}$

Memenuhi (obligation to fulfill): merupakan kewajiban dan tanggung jawab aparat penegak hukum khususnya Bapas untuk bertindak secara aktif agar semua warga negaranya itu bisa terpenuhi hak-haknya. Negara berkewajiban untuk mengambil langkah-langkah legislatif, administratif, hukum, dan tindakan-tindakan lain untuk merealisasikan secara penuh hak asasi anak. ${ }^{35}$

Kewajiban untuk menghormati, melindungi dan memenuhi Hak Anak, masing-masing mengandung unsur kewajiban aparat penegak hukum dan masyarakat untuk bertindak (obligation to conduct) serta kewajiban untuk berdampak (obligation to result):

Kewajiban untuk bertindak (obligation to conduct): mensyaratkan aparat penegak hukum khususnya Bapas melakukan langkah-langkah tertentu untuk melaksanakan pemenuhan suatu hak, yaitu melindungi hak anak dalam proses peradilan diperlukan prasarana dan sarana, serta sumber daya manusia yang memadai sesuai dengan peraturan yang mengaturnya Bahkan memberikan alternatif solusi dalam penanganan anak yang berkonflik dengan hukum sehingga dapat mencegah timbulnya masalah baru apabila anak tetap di proses diperadilan melalui hasil Penelitian Kemasyarakatan. ${ }^{36}$

Kewajiban untuk berdampak (obligation to result), yaitu mendorong aparat penegak hukum/
34. Ibid, hlm. 8

35. Ibid, hlm. 8

36. Ibid, hlm. 8 
Bapas untuk mencapai sasaran tertentu guna memenuhi standar substansif yang terukur. Aparat penegak hukum memberikan perhatian yang khusus dan terus menerus tentang perlindungan anak tidak hanya anak yang berkonflik dengan hukum tetapi di semua kehidupan sehingga pemenuhan, penghormatan dan perlindungan bagi anak dapat tercapai sesuai dengan standar HAM Internasional (Konvensi Hak Anak). ${ }^{37}$

Tentunya pelaksanaan dilakukan oleh pranata/lembaga dalam Sistem Peradilan Pidana Anak untuk melindungi anak yang berkonflik dengan hukum harus berlandaskan Hak Asasi Manusia, khususnya pemenuhan, penghormatan dan perlindungan anak tidak lepas dari asas Pancasila dan berlandaskan kepada Undangundang Dasar 1945 serta prinsip-prinsip dasar Konvensi Hak Anak meliputi: ${ }^{38}$

1) Nondiskriminasi,

2) Kepentingan yang terbaik bagi anak,

3) Hak untuk hidup, kelangsungan hidup dan perkembangan,

4) Penghargaan terhadap pendapat anak.

Dalam kaitannya dengan penguatan peran BAPAS, dalam undang-undang ini pembimbing kemasyarakatan (sering disebut sebagai PK BAPAS) tidak lagi bekerja secara mandiri, namun lebih diarahkan pada sinergi antar komponen petugas kemasyarakatan. Pasal 61 Undang-undang No. 11 Tahun 2012 tentang Sistem Pengadilan Pidana Anak tersebut menggambarkan sinergi dari ketiga komponen petugas kemasyarakatan sebagaimana yang disebutkan pula di dalam Pasal 65 Ayat 2 dan 67 Ayat 2. Sinergi tersebut harus terus diperkuat pada tiap tahapan dalam sistem peradilan anak dengan tetap memperhatikan tugas pokok masing-masing komponen yang ada. Namun demikian hambatan "klasik" masih menjadi faktor penghambat penguatan peran BAPAS.

Penanganan anak yang berhadapan dengan hukum berdasarkan Sistem Peradilan Pidana Anak tidak terlepas adanya faktor-faktor yang mempengaruhi pelaksanaannya yaitu faktor pendukung dan penghambat. ${ }^{39}$ Pembahasan mengenai faktor pendukung dan penghambat tertera di bawah ini berdasarkan pemikiran Soerjono Soekanto mengenai 5 (lima) faktor yang mempengaruhi penegakan hukum di masyarakat.
1) Faktor hukumnya sendiri (Peraturan Perundang-undangan)

Upaya dukungan yang dilakukan oleh negara (pemerintah) untuk menerbitkan kebijakan atau peraturan perundang-undangan dalam rangka penanganan anak yang berhadapan dengan hukum telah diberlakukan yaitu:

- Undang-undang No. 12 Tahun 1995 tentang Pemasyarakatan, mengupayakan mempercepat pembebasan bagi anak yang telah masuk dalam lembaga pemasyarakatan.

- Undang-undang No. 39 Tahun 1999 tentang Hak Asasi Manusia, yang intinya dari pasal 52-66 adalah menyatakan bahwa setiap anak berhak tidak dijadikan sasaran penganiayaan, penyiksaan atau penjatuhan hukuman yang tidak manusiawi, tidak dirampas kebebasannya secara melawan hukum. Hukuman mati atau hukuman seumur hidup tidak adapat dijatuhkan pada mereka. Penangkapan, penahanan atau pidana penjara anak hanya dapat dilaksanakan sebagai upaya terakhir.

- Undang-undang No. 35 Tahun 2014 tentang Perlindungan Anak, yang intinya mengatakan bahwa perlindungan khusus bagi anak yang berhadapan dengan hukum dilaksanakan melalui: perlakuan secara manusiawi sesuai hak-hak anak, penyediaan petugas pendamping khusus sejak dini, penyediaan sarana dan prasarana khusus, penjatuhan sanksi yang tepat untuk kepentingan yang terbaik bagi anak, pemantauan dan pencatatan terus menerus terhadap perkembangan anak yang berhadapan dengan hukum, jaminan untuk mempertahankan hubungan dengan orang tua atau keluarga dan perlindungan dari pemberitaan media/labelisasi

- Undang-undang No. 11 Tahun 2012 tentang Sistem Peradilan Pidana Anak (SPPA) salah satu pasalnya yaitu: Pasal 5 Ayat

37. Ibid, hlm. 9

38. Lihat Undang-undang No. 35 Tahun 2014 tentang Perlindungan Anak, Pasal 2.

39. Lihat Soerjono Soekanto, Faktor-faktor yang Mempengaruhi Penegakan Hukum, RajaGrafindo Persada, Jakarta, 2008. 
(1) menyebutkan bahwa; dalam sistem peradilan pidana anak wajib mengutamakan pendekatan keadilan restoratif. Kemudian pada Ayat (3) nya juga disebutkan bahwa; dalam sistem peradilan pidana anak wajib diupayakan diversi

- Keputusan Bersama 6 (enam) Instansi yakni: Mahkamah Agung, Kepolisian RI, Kejaksaan Agung, Kementerian Hukum dan HAM, Kementerian Sosial, dan Kementerian Negara Pemberdayaan Perempuan dan Perlindungan Anak Republik Indonesia tentang Penanganan Anak yang Berhadapan dengan Hukum. Keputusan Bersama ini dimaksudkan untuk mewujudkan keterpaduan dalam upaya penyelesaian perkara Penanganan Anak yang Berhadapan dengan Hukum yang dilakukan secara terkoordinasi oleh aparat penegak hukum dan semua pihak terkait.

- Peraturan Kepala Kepolisian Negara Republik Indonesia Nomor 12 Tahun 2009 tentang Pengawasan dan Pengendalian Penanganan Perkara Pidana di Lingkungan Kepolisian Negara republik Indonesia. Peraturan Kepala Kepolisian RI ini menegaskan peran BAPAS seperti yang disebutkan dalam Pasal 105, dinyatakan bahwa Dalam hal melaksanakan tindakan pemeriksaan terhadap anak, petugas wajib mempertimbangkan hak untuk mendapatkan petugas pendamping khusus untuk anak yaitu hak untuk didampingi oleh BAPAS dan orang tua.

2) Faktor penegak hukum

Hambatan yang ditemui dalam rangka penanganan anak yang berhadapan dengan hukum yaitu faktor penegak hukumitu sendiri diantaranya:

- Terjadinya singgungan antar komponen disebabkan menguatnya sikap ego sektoral diantara komponen Integrated Criminal Justice System (ICJS) yang ada ;

- Keterlambatan proses disebabkan birokrasi;

- Kurangnya komitmen untuk berkoordinasi antar lintas sektoral (kelembagaan) dalam sistem peradilan pidana anak.

- Lemahnya tindak lanjut terhadap kesepakatan dan komitmen yang dibuat, yaitu dalam Surat Keputusan Bersama antara Ketua Mahkamah
Agung; Jaksa Agung; Kepala Kepolisian Negara; Menteri Hukum dan HAM; Menteri Sosial; dan Menteri Negara Pemberdayaan Perempuan dan Perlindungan Anak tentang Penanganan $\mathrm{ABH}$.

- Kepolisian dan Kementerian Hukum dan HAM c.q Pemasyarakatan sebagai bagian dari proses penanganan Pidana Terpadu tidak mampu berbuat banyak untuk mengusahakan diversi, sehingga mengakibatkan over capacity penghuni di Lembaga Pemasyarakatan dan Rumah Tahanan, dan selanjutnya mempersempit ruang gerak Pembinaan maupun Pembimbingan terhadap Warga Binaan maupun Anak Didik Pemasyarakatan.

- Keterlambatan pendampingan $\mathrm{ABH}$ oleh pihak BAPAS, karena keterlambatan penyampain surat pendampingan dari Kepolisian. Sebenarnya sudah jelas dalam Peraturan Kepala Kepolisian Negara Republik Indonesia Nomor 12 Tahun 2009 menyatakan bahwa anak harus didampingi BAPAS pada saat masuk dalam proses penyidikan.

Dukungan yang dapat ditemui dalam penanganan $\mathrm{ABH}$ pada faktor penegak hukum adalah:

- Penguatan Peran BAPAS berupa kerja sama antar instansi terkait, guna memperkecil kesenjangan dalam forum Integrated Criminal Justice System (ICJS);

- Meningkatkan Pelaksanaan Pembimbingan dan Pengawasan yang dilakukan oleh BAPAS berkoordinasi dengan Dinas Sosial guna mengantisipasi pengulangan kembali dilakukannya tindak pidana serta pemulihan psikis anak melalui konsultasi sosial dalam rangka mengembalikan kepercayaan diri anak (advokasi sosial) ;

- Memberikan akses informasi kepada kejaksaan, kepolisian dan hakim tentang adanya rumah aman bagi anak yang berhadapan dengan hukum;

3) Faktor sarana atau fasilitas

Hambatan yang ditemui dalam penanganan $\mathrm{ABH}$ yaitu faktor sarana dan fasilitas, diantaranya: 
- Belum adanya SDM maupun sarana yang diamanahkan dalam undang-undang sistem peradilan pidana anak, seperti adanya pekerja kerja sosial professional; tenaga kesejahteraan sosial, dan lembaga penempatan anak sementara (LPAS).

- Terbatasnya Anggaran yang dialokasikan guna pelaksanaan tugas pembimbingan dan pendampingan Anak yang Berkonflik dengan Hukum (ABH).

Dukungan yang dapat ditemui dalam penanganan $\mathrm{ABH}$ pada faktor sarana dan fasilitas adalah:

- Adanya usulan dibentuknya BAPAS di tiaptiap Kab/Kota guna mengatasi keterbatasan jangkauan wilayah tugas serta dilengkapi dengan sarana pendukung berupa; "Rumah Pengembangan Kepribadian Anak/remaja yang sedang berhadapan dengan Hukum/ $\mathrm{ABH}$, tetapi bukan bentuk bangunan LAPAS ANAK meskipun berubah nama menjadi Lembaga Pemasyarakatn Khusus Anak (LPKA)“, guna kepentingan terbaik bagi anak pasca mediasi dalam pelaksanaan restorative justice.

- Adanya usulan dialokasikan dana khusus guna mendukung pelaksanaan tugas pembimbingan dan pengawasan dan pendampingan ABH oleh BAPAS; dan

4) Faktor masyarakat

Hambatan yang ditemui oleh pemerintah atau negara dalam penanganan $\mathrm{ABH}$ adalah faktor masyarakat itu sendiri seperti:

- Sudut pandang masyarakat terhadap kejahatan atau pelanggaran hukum yang dilakukan oleh anak meskipun masih dikategorikan belum dewasa tetap dianggap sebagai pelaku kejahatan dan di hukum, sebagai contoh kasus mencuri kotak amal masjid sebesar 37 ribu rupiah, pihak masjid mau berdamai, jika diganti-rugi sebesar lima juta rupiah. Apabila tidak dibayar dengan jumlah demikian tetap di proses hukum.

- Pemahaman masyarakat tentang arti pentingnya perlindungan hak anak khususnya anak yang berhadapan dengan hukum, sehingga HAM dari anak tersebut tidak terlanggar.

\section{5) Faktor kebudayaan}

Hambatan yang ditemui oleh pemerintah atau negara dalam penanganan $\mathrm{ABH}$ adalah faktor kebudayaan itu sendiri seperti:

- Aparat penegak hukum (BAPAS) menemui kesulitan mengenai penanganan $\mathrm{ABH}$ disebabkan nilai-nilai atau kebiasaan yang ada di masyarakat berbeda meskipun berada dalam satu wilayah atau daerah yang sama.

- Pemahaman masyarakat negatif terhadap anak yang melakukan pelanggaran hukum sehingga aparat penegak hukum mengalami kendala dalam perlindungan hak $\mathrm{ABH}$.

- Adanya aturan hukum yang tidak tertulis yang berada di masyarakat sehingga penanganan bagi anak yang melakukan pelanggaran hukum tidak di proses oleh aparat penegak hukum nanum cukup dilakukan oleh aparat desa atau kepala dusun setempat.

\section{KESIMPULAN}

Belum maksimalnya perlindungan hak anak dalam peran BAPAS untuk pembimbingan dan pendampingan oleh, yaitu: masih ditemukan keterlambatan pembuatan litmas dan pendampingan, dikarenakan adanya keterlambatan surat dari kepolisian untuk membuat Litmas dan pendampingan oleh BAPAS. Kurangnya upaya perdamaian (diversi) yang dilakukan oleh Kepolisian dan BAPAS dan masih adanya pelanggaran terhadap hak anak oleh aparat hukum (terutama terhadap psikis Anak Berkonflik dengan Hukum $(\mathrm{ABH})$ ). Undang-Undang Sistem Peradilan Pidana Anak (UU No.11/2012) sudah mengamanahkan bahwa demi kepentingan terbaik untuk anak maka $\mathrm{ABH}$ harus dilindungi melalui keterlibatan BAPAS sehingga hasil Penelitian Kemasyarakatan (PK) berkualitas sehingga menjadi pertimbangan aparat hukum yang lain khususnya hakim.

\section{SARAN}

Penguatan Peran BAPAS, guna memperkecil kesenjangan dalam forum Integrated Criminal Justice System (ICJS), berupa Peningkatan Pelaksanaan koordinasi dengan pemangku kepentingan terutama pihak Kepolisian dalam rangka Pendampingan, Pembimbingan dan 
Pengawasan serta mengantisipasi pengulangan kembali dilakukannya tindak pidana.

Pengusulan pengalokasian anggaran khusus guna mendukung pelaksanaan tugas pendampingan, pembimbingan dan pengawasan serta pendampingan sidang Anak (ABH) dan terhadap Klien Pemasyarakatan, pengusulan pelaksanaan diklat dan sertifikasi kompetensi terhadap personal PK BAPAS, guna peningkatkan profesionalisme, penunjukan PK Bapas Exopissio terhadap petugas Lapas/Rutan yang memiliki kompetensi dan dedikasi dalam bidang penanganan ABH di daerah yang sulit terjangkau oleh Kantor BAPAS. 


\section{DAFTAR PUSTAKA}

\section{Buku:}

Buku Pedoman Perlindungan Terhadap Anak yang Berhadapan dengan Hukum, kerjasama antara POLRI- UNICEF, 2004.

Gultom, Maidin, Perlindungan Hukum Terhadap Anak dalam Sistem Peradilan Pidana Anak di Indonesia, Refika Aditama, Jakarta, 2008

Gultom, M.Perlindungan Hukum terhadap Anak. Bandung: PT. Refika Aditama, 2013.

Margaretha, dkk. Buku Panduan Penanganan Anak Berhadapan dengan Hukum.Jakarta:P2TP2A (Pusat pelayanan terpadu pemberdayaan perempuan dan anak), 2012.

Muladi, Kapita Selekta Sistem Peradilan Pidana, Badan Penerbit Cetakan ke II, Universitas Diponegoro, Semarang, 2004.

Muladi sebagaimana dikutip oleh Eriyantouw Wahid, Keadilan Restoratif dan Peradilan Konvensional dalam Hukum Pidana, Penerbit Universitas Trisakti, Jakarta, 2009.

Muladi dan Barda Nawawi, A.Bunga Rampai Hukum Pidana. Bandung : PT. Alumni, 2010.

Nuraheni, Novie Amalia, Sistem Pembinaan Edukatif Terhadap Anak Sebagai Pelaku Tindak Pidana (Semarang : Universitas Diponogoro, 2009).

Pembangunan Berbasis Hak Asasi Manusia: Sebuah Panduan, Kerja sama antara Komisi Nasional Hak Asasi Manusia (KOMNAS HAM) dengan Australian Government (AusAID).

Perlindungan Anak, Sebuah Buku Panduan bagi Anggota Dewan Perwakilan Rakyat, InterParlementary Union, 2004.

Prasetyo dan Halim. Politik Hukum Pidana. Yogyakarta: Pustaka Pelajar, 2005.

Sambas, N..Pembaruan Sistem Pemidanaan Anak di Indonesia.Bandung: Refika Aditama, 2010

Soekanto, Soerjono, Faktor-faktor yang Mempengaruhi Penegakan Hukum, RajaGrafindo Persada, Jakarta, 2008.

Susilowati, Upaya Meminimalisasi Penggunaan Pidana Penjara Bagi Anak, (Semarang, Universitas Diponogoro, 2008
Surbakti, Natangsa, Sifat Melawan Hukum Materiel dan Implikasinya terhadap HAM Kolektif Atas Pembangunan di Indonesia, dalam Muladi (ed), Hak Asasi Manusia, Hakekat, Konsep dan Implikasinya dalam Perspektif Hukum dan Masyarakat, cet. 1., PT. Refika Aditama, Bandung, 2005.

Sutandyo Wignjosoebroto, "Hukum Konsep dan Metode”, (Malang: Setara Press, 2013).

Sutatiek. Rekonstruksi Sistem Sanksi dalam Hukum Pidana Anak di Indonesia, Urgensi Penerbitan Panduan Pemidanaan (The Sentencing Guidlines) untuk Hakim Anak. Yogyakarta: Aswaja Presindo, 2013.

Suwandi, Instrumen dan Penegakan HAM di Indonesia, dalam Muladi (ed), Hak Asasi Manusia, Hakekat, Konsep dan Implikasinya dalam Perspektif Hukum dan Masyarakat, cet. I., PT. Refika Aditama, Bandung, 2005

Wagiati Soetodjo, Hukum Pidana Anak, Cetakan Kedua, Refika Aditama, 2008.

Wahyudi, S. Implementasi Diversi dalam Pembaharuan Sistem Peadilan Pidana Anak di Indonesia.Purwokerto;Genta Publishing, 2011.

\section{Regulasi Internasional dan Nasional:}

General Assembly resolution 40/33 of 29 November 1985

Dalam instrumen internasional kelompok rentan itu meliputi, refugees, internally displaced persons (IDPS), national minorities, migrant workers, indigenous peoples, children; dan women. Sedangkan dalam UU No. 39 tahun 1999 tentang HAM Indonesia dalam penjelasannya disebutkan bahwa kelompok rentan itu meliputi orang lanjut usia, anakanak, fakir miskin, wanita hamil dan penyandang cacat.

Konvensi Hak-Hak Anak (diratifikasi melalui Keputusan Presiden Nomor 36 Tahun 1990)

Peraturan-Peraturan Minimum Standar PBB mengenai Administrasi Peradilan Bagi Anak (Beijing Rules), Resolusi Majelis PBB No.40/33 tanggal 29 November 1985 
Pedoman Perserikatan Bangsa-Bangsa tentang Pencegahan Tindak Pidana Anak (Riyadh Guidelines), Resolusi Majelis PBB No.45/112 tanggal 14 Desember 1990

Peraturan PBB untuk Perlindungan Anak yang Dicabut Kebebasannya (Havana Rule/ Juvenile Deprived Liberty), Resolusi Majelis PBB No.45/113 tanggal 14 Desember 1990

Undang-Undang Nomor 12 Tahun 1995, tentang Pemasyarakatan.

Undang-Undang Nomor 35 Tahun 2014, tentang Perlindungan Anak

Undang-Undang Nomor 11 Tahun 2012 tentang Sistem Peradilan Pidana Anak (SPPA).

\section{Sumber Lain:}

\section{Jurnal, Laporan Penelitian,Website}

Anggraeni U.R. Jurnal Supermasi Hukum: Peranan Pembimbing Kemasyarakatan di dalam Sistem Peradilan Pidana Anak di Kota Bengkulu. Bengkulu: Universitas Bengkulu. Volume 22 No.1. Januari 2013.

Gunarto, Peranan Bapas Dalam Perkara Anak, diunduh dari http://bangopick.wordpress. com/2008/02/09/peranan-bapas-dalamperkara-anak/ tanggal 26 Oktober 2017

M. Syafie, Perlindungan dan Hak-Hak Anak Yang berkonflik dengan Hukum diunduh dari http://www.docstoc.com/.../ANAK-YANGBERKONFLIK-DENGAN-HUKUM , diakses pada 30 Oktober 2017

Menggugat Peran Negara, Pemerintah, Masyarakat dan Orang Tua dalam Menjaga dan http:// komnaspa.wordpress.com/2011/12/21/ catatan-akhir-tahun-2011-komisi-nasionalperlindungan-anak/ 